\title{
PENGEMBANGAN PEMAHAMAN KONSEP DAN KEMAMPUAN PEMECAHAN MASALAH DALAM MEMBENTUK MODEL MATEMATIKA MELALUI STRATEGI PEMBELAJARAN INQUIRY BAGI MAHASISWA PRODI PENDIDIKAN MATEMATIKA UNIVERSITAS KANJURUHAN MALANG
}

\author{
Nur Farida \\ Dosen Pendidikan Matematika Universitas Kanjuruhan Malang \\ Email: faridanaufal22@gmail.com
}

\begin{abstract}
Abstrak
Pemahaman terhadap matematika, dari kemampuan yang bersifat keahlian sampai kepada pemahaman yang bersifat apresiatif akan berhasil mengembangkan kemampuan sains dan teknologi yang cukup tinggi. Proses pembelajaran membutuhkan metode yang tepat. Kesalahan menggunakan metode dapat menghambat tercapainya tujuan pendidikan yang diinginkan. Dampak lain adalah rendahnya kemampuan bernalar siswa dalam pembelajaran matematika. Hal ini disebabkan karena dalam proses siswa kurang dilibatkan dalam situasi optimal untuk belajar, pembelajaran cenderung berpusat pada guru dan klasikal. Selain itu siswa kurang dilatih untuk menganalisis permasalahan matematika, jarang sekali siswa menyampaikan ide untuk menjawab pertanyaan bagaimana proses penyelesaian soal yang dilontarkan guru. Pemecahan masalah dibangun oleh konsep-konsep pemecahan dan pemecahan masalah. Masalah (problem) adalah suatu situasi yang tak jelas jalan pemecahannya yang mengkonfrontasikan individu atau kelompok untuk. Berdasarkan hasil tes 1 diperoleh persentase 77,39\% dengan kriteria cukup. Sedangkan hasil tes 2 diperoleh persentase 83,04\% dengan kriteria baik. Dari hasil tersebut, maka dapat dikatakan bahwa proses penelitian melalui strategi inquiry dengan pemecahan masalah sudah berhasil, sehingga proses penelitian sudah selesai.
\end{abstract}

\section{Kata Kunci: Pemahaman konsep, pemecahan masalah, strategi inquiry, model matematika}

\begin{abstract}
Understanding of mathematics, from the ability of expertise through appreciative understading will develop the ability of science and technology quite high and successfully. The learning process requires appropriate methods. Mistakes using methods could impede the achievement of the desired educational goals. Another impact is the lack of reasoning ability of students in the learning of mathematics. This is because students are less involved in the process in an optimal situation for learning, the learning tends to be centered on teacher and classical. In addition, students are less trained to analyze the problems of mathematics, students rarely convey ideas to answer the question about how to solve problem was given by teacher. Problem solving is developed by solving concepts and problem solving. Problem is a situation that the solution does not clear that confront individuals or groups. Based on test 1 results obtained $77.39 \%$ with sufficient criteria. While the second test results obtained $83.04 \%$ with good criteria. From these results, it can be said that the research process through inquiry strategy with problem solving have been successful, so the research process has been completed.
\end{abstract}

Keywords: Understanding the concepts, problem solving, inquiry strategy, mathematical models

Pendidikan matematika merupakan salah satu fondasi dari kemampuan sains dan teknologi. Pemahaman terhadap matematika, dari kemampuan yang bersifat keahlian sampai kepada pemahaman yang bersifat apresiatif akan berhasil mengembangkan kemampuan sains dan teknologi yang cukup tinggi (Buchori, 2001). Pembelajaran merupakan komunikasi dua arah, mengajar dilakukan oleh pihak guru sebagai pendidik, sedangkan belajar dilakukan oleh pesrta didik atau siswa (Sagala, 2006:61). 
Proses pembelajaran membutuhkan metode yang tepat. Kesalahan menggunakan metode dapat menghambat tercapainya tujuan pendidikan yang diinginkan. Dampak lain adalah rendahnya kemampuan bernalar siswa dalam pembelajaran matematika. Hal ini disebabkan karena dalam proses siswa kurang dilibatkan dalam situasi optimal untuk belajar, pembelajaran cenderung berpusat pada guru dan klasikal. Selain itu siswa kurang dilatih untuk menganalisis permasalahan matematika, jarang sekali siswa menyampaikan ide untuk menjawab pertanyaan bagaimana proses penyelesaian soal yang dilontarkan guru.

Pemecahan masalah dibangun oleh konsep-konsep pemecahan dan pemecahan masalah. Masalah (problem) adalah suatu situasi yang tak jelas jalan pemecahannya yang mengkonfrontasikan individu atau kelompok untuk menemukan jawaban. Pemecahan masalah (problem solving) adalah upaya individu atau kelompok untuk menemukan jawaban berdasarkan pemahaman yang telah dimiliki sebelumnya dalam rangka memenuhi tuntutan situasi yang tak lumrah (Krulik \& Rudnick, 1996). Jadi aktivitas pemecahan masalah diawali dengan konfrontasi dan berakhir apabila sebuah jawaban telah diperoleh sesuai dengan kondisi masalah.

Salah satu metode pembelajaran matematika yang dapat diterapkan dalam mengantisipasi masalah yang timbul selama proses pembelajaran matematika adalah metode pembelajaran inkuiri. Diharapkan dengan metode pembelajaran inkuiri, siswa dapat mengembangkan konsep dan kemampuan memecahkan masalah untuk mencari dan menemukan sendiri jawaban dari suatu masalah atau problem yang dipertanyakan.

Pengembangan pemahaman konsep dan kemampuan pemecahan masalah matematika dalam membentuk model matematika umumnya terjadi melalui proses perubahan konseptual secara berkelanjutan. Oleh sebab itu, belajar untuk pengembangan pemahaman dan kemampuan pemecahan masalah matematika tidak dapat dilepaskan dari model perubahan konseptual.

Adapun tujuan yang akan dicapai dalam penelitian ini adalah: Mendeskripsikan proses pengembangan pemahaman konsep dan kemampuan pemecahan masalah dalam membentuk model matematika melalui strategi pembelajaran inquiry bagi mahasiswa prodi pendidikan matematika Universitas Kanjuruhan Malang dan menghasilakan perbedaan pemahaman konsepdan kemampuan pemecahan masalah dalam membentuk model matematika melalui strategi pembelajaran inquiry bagi mahasiswa prodi pendidikan matematika Universitas Kanjuruhan Malang.

\section{Metode Penelitian}

Penelitian ini berusaha untuk meningkatkan kemampuan pemahaman konsep dan pemecahan masalah melalui pembelajaran inquiry pada materi program linear. Data yang akan dikumpulkan dalam penelitian ini bersifat deskriptif, yaitu mengena ikemampuan pemahaman konsep dan pemecahan masalah pada program linear. Dengan demikian pendekatan yang tepat untuk digunakan adalah pendekatan kualitatif.

Jenis penelitian ini adalah penelitian tindakan kelas, karena dalam 
penelitian ini peneliti terlibat langsung dalam proses penelitian mulai awal sampai akhir penelitian, yang melibatkan dosen sebagai praktisi dan teman sejawat sebagai pengamat.

Dalam penelitian ini, teknik pengumpulan data dilakukan pada setiap kegiatan siswa dan situasi yang berkaitan dengan penelitian menggunakan instrumen berupa tes, lembar kerja mahasiswa, dan lembar observasi guru dan siswa. Test berupa postest setiap akhir siklus. Untuk menunjang kebenaran dari jawaban siswa maka dilengkapi dengan lembar observasi yang diisi oleh observer.

\section{Hasil Penelitian dan Pembahasan Siklus I}

\section{Perencanaan}

Pada tahap perencanaan ada beberapa hal-hal yang telah dipersiapkan, yaitu: (1) Rencana Pelaksanaan Pembelajaran (RPP) sebanyak 2, (2) Menyiapkan lembar observasi dosen dan mahasiswa, (3) Menyiapkan lembar validasi instrumen, dan (4) Menyiapkan lembar kerja mahasiswa sesuai materi yang akan diberikan.

\section{Pelaksanaan Pembelajaran}

Pelaksanaan validasi instrumen penelitian dilakukan pada tanggal 13 Pebruari 2015 dan dilakukan oleh seorang validator yaitu Ibu Dra. Retno Marsitin, M.Pd. Pada proses validasi, validator langsung memvalidasi instrumen penelitian kemudian menuliskan komentar dan saran-saran perbaikan pada perangkat yang divalidasi dan lembar validasi.

Pelaksanaan pembelajaran dibedakan menjadi 2 yaitu pembelajaran tentang mengubah soal cerita dalam bentuk matematis dan menyelesaikan persoalan tersebut setelah diubah dalam bentuk matematis.Pembelajaran dimulai dengan memberikan instruksi kepada mahasiswa agar mengikuti petunjuk yang terdapat pada masing-masing lembar kerja mahasiswa. Proses yang perlu dilakukan mahasiswa secara bertahap.berikutnya mahasiswa mulai mengerjakan LKM yang sudah dibagikan dengan kelompoknya.

Berdasarkan hasil tes 1 diperoleh persentase $77,39 \%$ dengan kriteria cukup. Tes 1 tersebut dilaksankan oleh 23 mahasiswa dari total 25 mahasiswa. Dua orang mahasiswa tidak dapat mengikuti kegiatan dikarenakan 1 mahasiswa dengan keterangan ijin melahirkan dan 1 mahasiswa lagi tidak pernah masuk dalam perkuliahan atau tanpa keterangan.

Hasil observasi digunakan untuk mengukur kesesuaian antara perencanaan terhadap pelaksanaan pembelajaran dan mengetahui persoalan-persoalan apa saja yang dihadapi selama kegiatan pembelajaran. Observasi ini dilakukan oleh pengamat penelitian yaitu 1 orang dosen dan peneliti sendiri. Hasil observasi tersebut akan menunjukkan bahwa aktifitas guru pada kegiatan pembelajaran pertama mencapai kategori baik yaitu dengan persentase $80 \%$, kegiatan pembelajaran kedua mencapai kategori baik dengan persentase baik $90 \%$, dan pembelajaran ketiga mencapai kategori sangat baik dengan persentase 95\%. Sedangkan untuk aktifitas mahasiswa pada pembelajaran pertama mencapai kategori cukup dengan persentase $75 \%$. Pada pembelajaran kedua mencapai kategori baik dengan persentase $85 \%$, dan pembelajaran ketiga mencapai kategori baik dengan persentase $90 \%$. 
Seperti telah diketahui sebelumnya bahwa hasil observasi aktifitas guru dan mahasiswa pada kegiatan pembelajaran siklus 1 belum sesuai kriteria yang diharapkan karena masih mencapai kriteria cukup dan baik. Demikian pula untuk LKM yang masih nampak 1 kelompok mahasiswa masih mencapai nilai kurang. Oleh sebab itu perlu diperbaiki untuk kegiatan pembelajaran berikutnya.

\section{Siklus II}

\section{Perencanaan}

Pada tahap perencanaan ada beberapa hal-hal yang telah dipersiapkan, yaitu: (1) Rencana Pelaksanaan Pembelajaran (RPP) sebanyak 2, (2) Menyiapkan lembar observasi dosen dan mahasiswa, dan (3) Menyiapkan lembar kerja mahasiswa sesuai materi yang akan diberikan.

\section{Pelaksanaan Pembelajaran}

Pelaksanaan pembelajaran dibedakan menjadi 2 yaitu pembelajaran tentang mengubah soal cerita dalam bentuk matematis dan menyelesaikan persoalan tersebut setelah diubah dalam bentuk matematis.. Selanjutnya peneliti memberikan penjelasan sepintas materi yang diberikan dan contohnya. Setelah itu peneliti menempatkan mahasiswa sesuai dengan kelompok-kelompoknya dan menyampaikan tugas dari masing-masing kelompok. Setelah peneliti menempatkan mahasiswa pada kelompok-kelompoknya, kemudian peneliti membagikan lembar kerja mahasiswa dan menjelskan langkahlangkah dalam menyelesaikannya.

Berdasarkan hasil tes 2 diperoleh persentase $83,04 \%$ dengan kriteria baik. Tes 2 tersebut dilaksankan oleh 23 mahasiswa dari total 25 mahasiswa. Dua orang mahasiswa tidak dapat mengikuti kegiatan dikarenakan 1 mahasiswa dengan keterangan ijin melahirkan dan 1 mahasiswa lagi tidak pernah masuk dalam perkuliahan atau tanpa keterangan.

Hasil observasi digunakan untuk mengukur kesesuaian antara perencanaan terhadap pelaksanaan pembelajaran dan mengetahui persoalan-persoalan apa saja yang dihadapi selama kegiatan pembelajaran. Observasi ini dilakukan oleh pengamat penelitian yaitu 1 orang dosen dan peneliti sendiri. Hasil observasi tersebut akan menunjukkan bahwa aktifitas guru pada kegiatan pembelajaran pertama mencapai kategori baik yaitu dengan persentase $80 \%$, kegiatan pembelajaran kedua mencapai kategori baik dengan persentase baik 90\%, dan pembelajaran ketiga mencapai kategori sangat baik dengan persentase $95 \%$. Sedangkan untuk aktifitas mahasiswa pada pembelajaran pertama mencapai kategori cukup dengan persentase $75 \%$. Pada pembelajaran kedua mencapai kategori baik dengan persentase $85 \%$, dan pembelajaran ketiga mencapai kategori baik dengan persentase $90 \%$.

Sebelum materi program linier diajarkan, peneliti mempersiapkan mahasiswa agar benar-benar siap untuk belajar. Kemudian dilanjutkan dengan menyampaikan tujuan perkuliahan dalam penelitian ini dapat memberikan motivasi belajar pada mahasiswa dan menjadikan fokus pada satu tujuan yang perlu mereka capai. Hal ini didukung oleh pendapat Orton (1992:9-10) bahwa mahasiswa yang termotivasi, tertarik, dan mempunyai keinginan untuk belajar akan belajar lebih banyak. 
Kegiatan pembelajaran untuk membantu mahasiswa dalam memahami materi mengubah soal cerita dalam bentuk matematik dan penyelesaiannya dilakukan dengan menggunakan LKM. LKM yang digunakan memuat berbagai macam soal cerita yang akan diubah dalam bentuk matematis dengan mengikuti beberapa langkah yang diberikan. Langkah tersebut diberikan secara bertahap mulai dari

1. Membaca dengan seksama soal cerita yang diberikan.

2. Mengambil beberapa informasi apa yang diperoleh dari soal cerita tersebut.

3. Menjabarkan informasi yang sudah diperoleh.

4. Merumuskan informasi tersebut dalam matematik.

5. Menyelesaikan soal setelah diubah dalam bentuk matematis.

Penggunaan LKM terbukti sangat membantu arah kerja mahasiswa. Langkahlangkah yang ditentukan dalam LKM merupakan suatu bentuk bantuan bagi mahasiswa. Hal-hal yang perlu dilakukan mahasiswa sehubungan langkah-langkah penyelesaian kasus dijelaskan dalam LKM. Meskipun demikian, LKM tidak menuntun mahasiswa secara mutlak. LKM hanya menguraikan langkah-langkah secara garis besar. Hal ini mendukung pendapat Machmud (2001:7) yang menyatakan bahwa lembar kerja dapat memberikan kesempatan kepada peserta didik untuk bekerja secara mandiri dan bekerja sama, serta memebrikan kesempatan kepada peserta didik untuk melakukan kegiatan penemuan.

Perkuliahan materi mengubah soal cerita ke bentuk matematik dalam penelitian ini dilakukan dengan membagi mahasiswa ke dalam kelompok yang terdiri dari 6 kelompok. Dalam kegiatan kelompok, setiap anggota kelompok saling mengutarakan ide atau gagasan dalam menyelesaikan persoalan yang lebih kompleks, kerja sama dan pertimbangan bagi anggota yang memiliki kemampuan kurang dapat didorong atau diberi penjelasan dengan anggota kelompok yang memiliki kemampuan lebih.

Penggunaan belajar secara berkelompok dalam penelitian ini memberikan banyak keuntungan bagi mahasiswa. Terbukti mahasiswa saling berdiskusi untuk menyelesaikan pekerjaannnya. Selanjutnya dosen mengadakan evaluasi melalui tanya jawab lisan untuk mengecek kembali pemahaman mahasiswa. Dosen perlu memastikan bahwa semua mahasiswa dapat memahami materi yang baru dipelajari. Sebagai penutup, atas arahan dan bimbingan dosen, mahasiswa menuliskan hasil diskusinya sebgai simpulan akhir perkuliahan. Hal ini didukung pendapat Degeng (1997:28) bahwa membuat rangkuman atau kesimpulan dari apa yang telah dipelajari perlu dilakukan untuk memepertahankan retensi.

\section{Simpulan}

Berdasarkan hasil penelitian dan pembahasan, maka kesimpulan yang dapat diambil dari penelitian ini bahwa tahaptahap yang dilakukan peneliti dalam melaksanakan kegiatan pembelajaran meliputi:

1. Kegiatan pembelajaran dilakukan dalam 3 tahap yaitu, tahap awal, tahap inti, dan tahap akhir. Aktifitas-aktifitas pengajar dari masing-masing tahapan adalah sebagai berikut: 
a. Tahap awal

1) Menyampaikan tujuan pembelajaran.

2) Menggali pengetahuan prasyarat materi yaitu materi persamaan dan pertidaksamaan.

3) Memberikan LKM sebagai bentuk bimbingan yang sudah memuat beberapa persoalan dan dilengkapi dengan langkah-langkah penyelesaiannya.

4) Menyampaikan aturan kegiatan pembelajaran diantaranya pengisian LKM dan pembagian kelompok.

5) Melakukan pengecekan bahwa mahasiswa sudah sesuai dengan kelompoknya dan selanjutnya menyelesaikan LKM.

b. Tahap inti

1) Memberikan kesempatan kepada mahasiswa untuk membaca dan memahami petunjuk yang diberikan di LKM dari persoalan yang diberikan.

2) Memantau kelompok dalam menyelesaikan LKM.

3) Memberikan bantuan kepada kelompok yang masih kebingungan terhadap penyelesaian persoalan pada LKM yang sudah diberikan.

4) Setelah menyelesaikan LKM, menugaskan perwakilan kelompok untuk mempresentasikan hasil kerjanya dan mendiskusikan dengan semua kelompok.

5) Mengatur proses pertanyaan yang akan diberikan oleh mahasiswa kepada kelompok yang presentasi.

6) Memberikan saran, masukan bagi kelompok yang presentasi dalam menjawab pertanyaan mahasiswa lain.

c. Tahap akhir

1) Memberikan review terhadap kegiatan pembelajaran termasuk di dalamnya kegiatan presentasi.

2) Memberi kesimpulan terhadap kegiatan pembelajaran yang telah dilaksanakan.

3) Memngingatkan materi yang akan dipelajari pada pertemuan berikutnya.

2. Hasil data untuk aktifitas guru pada siklus I dan siklus II berturut-turut dalam kategori baik, baik dan sangat baik. Sedangkan aktifitas mahasiswa mencapai .kategori cukup, baik, dan baik. Oleh sebab itu, kriteria keberhasilan pada aspek pengamatan telah tercapai.

3. Hasil data LKM menunjukkan bahwa pada siklus I ada 1 kelompok yang belum mencapai kriteria ditetapkan, namun 5 kelompok yang lain sudah mencapai. Sedangkan pada siklus II semua kelompok sudah mencapai kriteria yang ditetapkan dengan kategori sangat baik. Oleh sebab itu, kriteria keberhasilan pada aspek ini telah tercapai.

4. Hasil data tes pada siklus I mencapai kriteria cukup, sedangkan pada siklus II mencapai kriteria baik. Oleh sebab itu, kriteria keberhasilan sudah mencapai yang ditetapkan. 
Berdasarkan hasil penelitian maka beberapa saran yang perlu diberikan diantaranya adalah

1. Bagi pembaca atau peneliti hendaknya menggunakan model pembelajaran yang variatif ketika melakukan pembelajaran.

2. Bagi mahasiswa hendaknya mampu berfikir secara kongkret dan memiliki keberanian dalam menyampaikan pendapatnya untuk penyelesaian persoalan.

\section{Pustaka Rujukan}

Arikunto, Suharsimi. 2002. Prosedur Penelitian: Suatu Pendekatan Praktek. Jakarta: RinekaCipta.

Gulo. 2005. Strategi Belajar Mengajar. Jakarta: PT. Grasindo.

Herdian. 2010. Model Pembelajaran Inquiri. Availabel at: http://herdy07. wordpress.com/2010/05/27/Model-

Pembelajaran-Inkuiri/.?

Krulik, S dan Rudnick, J.A. 1995. The New Sourcebook for Teaching Reasoning and Problem Solving in Elementary School. Massachusetts: Allyn \& Bacon A Simon \& Schuster Company.

Machmud, T. 2001. Implementasi PAM Untuk Meningkatkan Kemampuan Siswa Dalam Menyelesaikan Soal Program Linear. Tesis (tidak diterbitkan). Malang: PPS-UM.

Mairy, Du. 2003. Matematika Terapan untuk Bisnisdan Ekonomi. Yogyakarta: PT. BPFE.
Mcniff. 2002. The Action Research Planner. Deakin University.

Orton, A. 1992. Learning Mathematics: Issue, Theory, and Practice. Great Britain: Redwood Books.

Sagala. 2006. Konsep dan Makna Pembelajaran. Jakarta: Alfabeta.

Sanjaya, Wina. 2008. Strategi Pembelajaran Berorientasi Standar Proses Pendidikan. Jakarta: Kencana.

Santyasa. 2006. Dimensi-dimensi Teoritis Peningkatan Profesionalisme Guru. (Online)

(http://staipuimajalengka.files.wordpre ss.com/2009/09/dimensi-teoritisprofesionalis-guru.pdf.

Tim Penyusun Diknas. 1991. Kamus Besar Bahasa Indonesia. Jakarta: Balai Pustaka

Wardani, I. G. A. K. 2003. Pendidikan Tindakan Kelas. Jakarta: Pusat Penerbitan Universitas Terbuka. 